\title{
O ENSINO DE HISTÓRIA NO ENSINO FUNDAMENTAL
}

\section{Luzia Aparecida da Silva Azevedo' Ana Enedi Prince ${ }^{2}$}

Resumo: Esse artigo discorre sobre o Ensino de História no Ensino Fundamental, considerando que ele deve ter como ponto de partida a história de vida do aluno, ou seja, a Identidade. Nesse contexto, o objetivo é que os alunos se reconheçam enquanto agentes da História por intermédio do desenvolvimento de metodologias apropriadas. Sendo assim, as práticas metodológicas desenvolvidas no ensino de História devem priorizar a contextualização, a valorização da sua própria história de vida e a reflexão do seu papel na sociedade, enquanto cidadão consciente de seus direitos e deveres, capazes de transformar a sociedade na qual estão inseridos, se constituem como funções do ensino de História.

Palavras-chave: História; Ensino fundamental, Metodologias; Identidade.

\footnotetext{
${ }^{1}$ História/Universidade do Vale do Paraíba, Brasil. E-mail: luzia-azevedo@hotmail.com.

${ }^{2}$ História/Universidade do Vale do Paraíba, Brasil. E-mail: prince@univap.br.
} 